Intolerance of uncertainty in seriously injured veterans: a comparative analysis

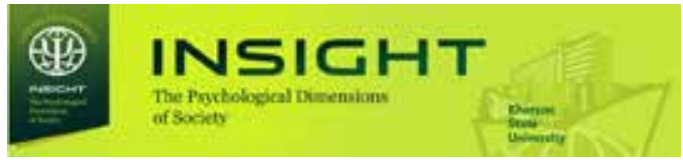

DOI: $10.32999 / 2663-970 X / 2020-4-2$

Link article (Style APA): Hromova H. M. (2020). Intolerance of uncertainty in seriously injured veterans: a comparative analysis. Insight: the psychological dimensions of society, 4, 29-41. DOI: $10.32999 / 2663-970 X / 2020-4-2$

Link article (Style DSTU 8302: 2015): Hromova, H. M. Intolerance of uncertainty in seriously injured veterans: a comparative analysis. Insight: the psychological dimensions of society, 2020, 4, 29-41. DOI: $10.32999 / 2663-970 X / 2020-4-2$

UDC 316.647.5:355.01-056.266

\title{
Intolerance of uncertainty in seriously injured veterans: a comparative analysis
}

\author{
Інтолерантність до невизначеності у ветеранів \\ з важкими пораненнями: порівняльний аналіз
}

Received: August 30, 2020 Accepted: November 06, 2020

\author{
Hromova Hanna Mykhailivna \\ Postgraduate student \\ Institute of Social and Political Psychology, \\ Ukraine \\ annagrom@gmail.com, \\ ORCID 0000-0002-6547-339X
}

\author{
Громова Ганна Михайлівна \\ аспірантка \\ Інститут соціальної та політичної \\ психології, Україна \\ annagrom@gmail.com, \\ ORCID 0000-0002-6547-339X
}

\begin{abstract}
Intolerance of uncertainty is seen as tendency to perceive unexpected and new circumstances as dangerous, and respond to them as a threat. It is known that the rejection of uncertainty is a factor that complicates the course and treatment of affective disorders (anxiety, depression, PTSD, sociophobia, etc.). The purpose of the research is to identify the relationship between intolerance of uncertainty and signs of PTSD in veterans with serious injuries or disabilities. Methods: using the parametric Student's t-criterion and the non-parametric Mann-Whitney and Kruskal-Wallis test, a comparative analysis was performed, and the Spearman coefficient $\rho$ was used to analyze the correlations. Data collected in two groups of servicemen were compared. Officers ( $n=47)$ and veterans who participated in the qualifying round of the Invictus Games $(n=32)$ completed the Intolerance of Uncertainty Scale questionnaire, the N. Carleton's short version, and the PCL-5 PTSD Symptom Questionnaire. Results: it was found that
\end{abstract}

\begin{abstract}
Анотація
Інтолерантність до невизначеності розглянуто як властивість сприймати несподівані та нові обставини як небезпечні, та реагувати на них як на загрозу. Відомо, що неприйняття невизначеності $є$ чинником, який ускладнює перебіг та лікування афективних розладів (тривожність, депресію, ПТСР, соціофобію та ін.). Метою дослідження $\epsilon$ визначення особливостей зв'язку інтолерантності до невизначеності з ознаками ПТСР у ветеранів з важкими пораненнями або інвалідністю. Методи: за допомогою параметричного критерію t-Стюдента та непараметричних критеріїв Манна-Уітні та Краскала-Уоліса був проведений порівняльний аналіз, для аналізування кореляцій використаний коефіціент $\rho$ Спірмена. Були співставлені дані, зібрані в двох групах військовослужбовців. Офіцери (n=47) та ветерани, що брали участь у відбірковому турі змагань “Ігри Нескорених", (n=32), заповнили опитувальники "Шкала інтолерантності до невизначеності”, модифікована версія Н. Карлетона, та опитувальник симптомів посттравматичного стресового
\end{abstract}


groups of servicemen do not differ in the general level of intolerance of uncertainty, but there was a significant difference on the scale of "depressing anxiety". Subgroups with a higher level of intolerance of uncertainty have significantly more manifestations of post-traumatic stress symptoms. Intolerance of uncertainty correlates with all clusters of PTSD symptoms in the general military group, and the "Inhibitory anxiety" subscale has a stronger correlation with all clusters than the "Perspective anxiety" subscale. Conclusions: for the first time, the connection between IU and signs of PTSD in servicemen was studied in the Ukrainian sample. Veterans with serious injuries and disabilities have higher scores on the "Inhibitory anxiety" subscale. The specificity of the connection between intolerance of uncertainty in veterans with serious injuries or disabilities, and signs of PTSD, is the lack of correlation with aggressive and self-destructive behaviour (symptoms of cluster E). This feature reflects the specifics of the experience and manifestations of aggression in veteran athletes with disabilities.

Keywords: intolerance of uncertainty, PTSD, veterans, comparative analysis, disability.

\section{Introduction}

Researchers of intolerance of uncertainty study a person's attitude to the obscurity and unpredictability of the world around him or her. Today, in the English literature, tolerance and intolerance of uncertainty are studied as two related but separate constructs, because in English the difference in terminology is more noticeable and has led to the separation of the terms "tolerance for ambiguity" and "intolerance of uncertainty", respectively. Intolerance of uncertainty is understood as theproperty ofanindividual to perceive uncertainty as unacceptable, dishonest feature, and to react to itas a threat. Researches of intolerance of uncertainty (IU) are currently numerous and confirm the association of IU with a number of negative affective states. There is evidence that IU is a transdiagnostic factor that complicates the treatment of affective disorders. K. Freeston's questionnaire and its short version made by N. Carleton (Carleton et al., 2007) are used to study IU as a transdiagnostic factor. In Ukraine, research on IU and its connection with negative emotional states has not been conducted, primarily due to the lack of translated, adapted and validated tools for this purpose. розладу PCL-5. Результати: 3'ясовано, що групи військовослужбовців не відрізняються за загальним рівнем інтолерантності до невизначеності, але $\epsilon$ значуща різниця за шкалою “гнітюча тривога". У підгрупи з більш високим рівнем інтолерантності до невизначеності значно більше проявів посттравматичного стресу. Інтолерантність до невизначеності корелює з усіма кластерами симптомів ПТСР в загальній групі військовослужбовців, субшкала "гнітюча тривога" має більш сильну кореляцію з усіма кластерами, ніж субшкала “тривога перед майбутнім". Висновки: Вперше на українській вибірці був досліджений зв'язок ITH з ознаками ПТСР у військовослужбовців. Ветерани з важкими пораненнями та інвалідністю мають більш високі бали за субшкалою “гнітюча тривога”. Специфікою зв'язку інтолерантності до невизначеності у ветеранів, що мають важкі поранення або інвалідність, з ознаками ПТСР $є$ відсутність кореляції з проявами агресії та самопошкоджувальною поведінкою (симптомами кластеру “Е”). Ця особливість відображає специфіку переживання та проявів агресії у ветеранів-спортсменів з обмеженими можливостями.

Ключові слова: інтолерантність до невизначеності, ПТСР, ветерани, порівняльний аналіз, інвалідність.

\section{Вступ}

Дослідники інтолерантності до невизначеності вивчають ставлення людини до невідомості та непередбачуваності навколишнього світу. Сьогодні в англомовній літературі толерантність та інтолерантність до невизначеності вивчається як два суміжних, але окремих конструкта, бо англійською різниця в термінології більш помітна і призвела до виокремлення термінів "tolerance for ambiguity" та "intolerance of uncertainty", відповідно. Під інтолерантністю до невизначеності розуміють властивість особистості сприймати невизначеність як неприйнятну, нечесну, та реагувати на неї як на загрозу. Дослідження інтолерантності до невизначеності (ITH) наразі чисельні і підтверджують зв'язок ІТН з низкою негативних афективних станів. $Є$ свідчення, що ITH $€$ трансдіагностичним фактором, що ускладнює лікування афективних розладів. Для вивчення ITH як трансдіагностичного чинника використовують опитувальник М. Фристона та його скорочену версію, зроблену Н. Карлетоном (Carleton et al., 2007). В Україні досліджень ITH та її зв'язку з негативними

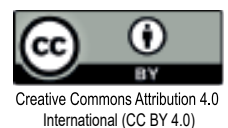


The object of our study is the experience of intolerance of uncertainty in people with traumatic experiences, because IU affects the severity of symptoms of depression and PTSD (Fetzner et al., 2013; Saulnier et al., 2019). According to statistics on the distribution of clinical disorders of the Veterans Health Administration of the United States of America (Veterans Health Administration, USA), these diagnoses are, respectively, first and second in frequency in the servicemen (Trivedi et al., 2015). There are no official statistics available in Ukraine, so we will focus on international data, assuming that the distribution of diseases is similar.

There are still few IU studies that link attitudes to uncertainty with signs of PTSD. Most of them are made on a sample of civilians, usually students. In particular, the hypothesis that a high level of intolerance of uncertainty is a factor that increases vulnerability to stress was tested on students. Level of IU and a variety of symptoms (anxiety, signs of PTSD) was measured before and after negative life events in two independent researches. Both studies confirmed that IU was a significant predictor of the development of signs of post-traumatic stress (Oglesby et al., 2016; Boelen, 2019).

The authors, who studied the relationship of IU with signs of PTSD in the servicemen, also found a significant contribution of intolerance of uncertainty in the developmentand maintenance of post-traumatic stress signs, in particular, in the symptoms of hyper arousal and reactivity. The samples consisted of servicemen who sought help in the clinic and were diagnosed with PTSD (Banducci et al., 2016; Raines et al., 2019), and demobilized veterans with combat experience (Zerach, Levi-Belz, 2019). The specifics of the attitude to uncertainty in veterans with serious injuries and / or disabilities in the world have not been studied. In Ukraine, the issue of the connection between intolerance of uncertainty and the development of negative emotional states and post-traumatic stress in the servicemen has also not been studied.

The probability of developing signs of PTSD, in addition to the presence of traumatic experience and individual characteristics, also has a social component: financial status, preservation / loss емоційними станами не проводилось, насамперед через брак перекладеного, адаптованого та валідизованого інструменту для цього.

Об'єктом нашого дослідження є переживання інтолерантності до невизначеності у осіб з травматичним досвідом, бо ІТН впливає на важкість симптомів депресії та ПТСР (Fetzner et al., 2013; Saulnier et al., 2019). 3a даними статистики розподілу клінічних розладів Управління здоров'я ветеранів США (Veterans Health Administration, USA) ці діагнози посідають, відповідно, перше і друге місце за частотою прояву у військових (Trivedi et al., 2015). В Україні немає доступної офіційної статистики, тому будемо орієнтуватися на міжнародний досвід, з припущенням, що розподіл захворювань $є$ схожим.

Досліджень ITH, присвячених зв'язку ставлення до невизначеності з ознаками ПТСР, досі небагато. Більшість з них зроблена на вибірці цивільних, зазвичай, студентів. Зокрема, на студентах була перевірена гіпотеза про те, що високий рівень інтолерантності до невизначеності є чинником, який збільшує вразливість до стресу. В незалежних дослідженнях, проведених у респондентів, був помірний рівень ITH та різноманітних симптомів (тривога, ознаки ПТС) до та після негативних подій ужитті. В обох дослідженнях було підтверджено, що ITH $є$ значущим предиктором розвитку ознак посттравматичного стресу (Oglesby et al., 2016; Boelen, 2019).

Автори, що вивчали зв'язок ITH з ознаками ПТСР у військових, також виявили значущий вклад інтолерантності до невизначеності у розвиток та підтримку ознак посттравматичного стресу, зокрема, в проявах гіперзбудження і реактивності. Вибірки складались 3 військових, що звертались за допомогою у клініку та у яких був діагностований посттравматичний стресовий розлад (Banducci et al., 2016; Raines et al., 2019), та демобілізованих ветеранів, що мають бойовий досвід (Zerach, Levi-Belz, 2019). Специфіка ставлення до невизначеності у ветеранів з важкими пораненнями та/або інвалідністю в світі не досліджувалась. В Україні питання зв'язку інтолерантності до невизначеності з розвитком негативних емоційних станів та посттравматичного стресу у військових також не вивчалась. 
of social status, the presence of social support from society and the surroundings. The research of the veterans of Afghanistan confirms the fact that there are much more adapted ones among socially active veterans than among socially passive ones; the severity of trauma (the presence of serious physical injuries, disability) significantly impede readaptation (Pidchasov, Lomakin, 2011). The connection with the symptoms of PTSD is reciprocal: the restriction of activity leads to manifestations of social psychological maladaptation, which exacerbates the symptoms of PTSD, which, in turn, actualizes alienation and leads to a decrease in social activity. Thus, rehabilitation and reintegration of veterans into peaceful life in personal, instrumental, spatial, temporal areas (Tytarenko, 2019) are important component of preventing the development of PTSD in veterans. The intolerance of uncertainty level should be the focus of attention as one of the strategies of a complex process of social psychological support at its diagnostic-target and community-communicative stages (Tytarenko, 2020).

The purpose of this study is to examine the relationship between intolerance of uncertainty and signs of PTSD in veterans with serious injuries or/and disabilities.

\section{Methodology}

\section{Participants}

The total sample consisted of two groups of servicemen. The sample No. 1 (hereinafter referred to as veterans) consisted of 32 servicemen who took part in the final selection for the Ukraine's Paralympic team in 2019 to participate in the competition "Invictus Games" 2020. The selection criteria for the final were the presence of confirmed serious injuries or disabilities, the formation of the desire to undergo rehabilitation, the ability to work in a team, sports ethics and a proactive attitude. The research was conducted on a voluntary basis; participants were informed about the objectives of the study and signed consent to data processing. A total of 38 respondents filled in the questionnaires, of which 6 were excluded from further analysis due to the incomplete filling process or many gaps
Вірогідність розвитку ознак ПТСР окрім наявності травматичного досвіду та індивідуальних характеристик людини має також і соціальний компонент: фінансове становище, збереження/втрата соціального статусу, наявність соціальної підтримки з боку суспільства та близького оточення. В дослідженні ветеранів-афганців підтверджується той факт, що серед соціально-активних ветеранів адаптованих значно більш, ніж серед соціально-пасивних; ступінь травматизації (наявність фізичних важких поранень, інвалідність) значно ускладнює реадаптацію (Підчасов, Ломакін, 2011). Зв'язок з симптомами ПТСР тут реципрокний: обмеження активності призводить до проявів соціально-психологічної дезадаптованості, яка сприяє загостренню симптомів ПТСР, що, в свою чергу, актуалізує відчуження та веде до зниження соціальної активності. Отже, реабілітація і реінтеграція ветеранів в мирне життя в персональному, інструментальному, просторовому, часовому напрямках (Титаренко, 2019) $є$ важливою складовою запобігання розвитку ПТСР у ветеранів. Рівень інтолерантності до невизначеності має бути в фокусі уваги у якості однієї зі стратегій комплексного процесу соціально-психологічного супроводу на його діагностико-цільовому та спільнотно-комунікативному етапах (Титаренко, 2020).

Метою цього дослідження $є$ вивчення особливостей зв'язку інтолерантності до невизначеності з ознаками ПТСР у ветеранів, що мають важкі поранення або інвалідність.

\section{Методологія}

\section{Учасники}

Загальну вибірку склали дві групи військовослужбовців. Вибірку №1 (далі ветерани) склали 32 військові, які брали участь у фінальному відборі в паралімпійську збірну України в 2019 році для участі у змаганнях "Ігри Нескорених" 2020. Критеріями відбору у фінал були наявність підтверджених важких поранень або інвалідності, сформованість бажання проходити реабілітацію, здатність працювати в команді, етика спорту та проактивна життєва позиція. Дослідження проводилось на добровільних засадах, учасники були проінформовані щодо цілей дослідження

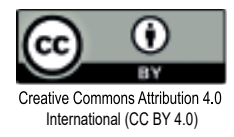


in the data. The mean age was 33.7 years (from 23 to 50 years, $S D=7.2$ ).

Sample No. 2 (hereinafter referred to as officers) consisted of servicemen, mostly with combat experience, who passed a master's program in one of the higher education institutions of the Ministry of Defence of Ukraine. The total number of respondents was 47 people, the mean age was 34.8 years (from 28 to 44 years, $\mathrm{SD}=3.7$ ).

Representatives of both samples filled in questionnaires, which are described in paragraph "Methodology".

\section{Methodology}

Intolerance of uncertainty scale, a short version of $N$. Carleton. The "Intolerance of Uncertainty Scale" test, a short version by N. Carleton (IUS-12) adapted by G. Hromova (in press) is an abbreviated version of the questionnaire "Intolerance of Uncertainty Scale" by M. Freeston (Carleton et al., 2007; Freeston, 1994). The test has total score and subscales: Perspective anxiety and Inhibitory anxiety. Respondents were asked to answer the Likert scale to what extent they agree with each question, where 1 - completely disagree, 5 - completely agree. Maximum total score was 60 .

The Posttraumatic Stress Disorder Checklist for DSM-5 (PCL-5). The PCL-5 questionnaire with criterion $A$ is a 20-point test designed to measure the symptoms of PTSD according to the DSM-5 criteria for PTSD (Karachevskyi A. B., 2016; Bovin M. J., 2015). After identifying the worst event by criterion $\mathrm{A}$, respondents answered questions about the various symptoms and the degree of their experience during the last month. The answers were rated using a five-point Likert-type scale ranging from 0 (not at all) to 4 (very strongly). Maximum possible total score is 80. Scores of 45 and higher indicate a significant probability of having PTSD. The Cronbach's alpha coefficient in the total sample was $\alpha=.94$.

\section{Stages of analysis}

Initially, a comparative analysis of two servicemen groups was conducted on the level of the general score of intolerance of uncertainty and on subscales. Also, the data of two groups were compared to determine the difference in the level of post-traumatic stress signs in servicemen with і підписали згоду на обробку даних. Всього заповнили анкети 38 респондентів, 3 них 6 анкет були відбраковані через незавершений процес заповнення, або багатьох пропусків в даних. Середній вік склав 33.7 років (від 23 до 50 р., SD = 7.2).

Вибірка №2 (далі - офіцери) - це військовослужбовці, що переважно мають бойовий досвід, які проходили магістерську програму в одному з ВНЗ Міністерства оборони України. Загальна кількість респондентів 47 осіб, середній вік 34.8 (від 28 до 44 р., SD = 3.7).

Представники обох вибірок діагностувалися за представленими нижче методиками.

\section{Методики}

Шкала інтолерантності до невизначеності, коротка версія Н. Карлетона. Тест "Шкала інтолерантності до невизначеності", коротка версія Н. Карлетона (IUS-12) в адаптації Г. Громової (готується до публікації) є скороченою версією опитувальника "Шкала інтолерантності до невизначеності” М. Фристона (Carleton et al., 2007; Freeston, 1994). Тест має загальний бал та дві шкали: тривога перед майбутнім і гнітюча тривога. Респондентам пропонується відповісти за шкалою Р. Лайкерта наскільки вони згодні з кожним запитанням, де 1 - зовсім не типово для мене, 5 - дуже характерно для мене. Максимальний загальний бал 60.

Опитувальник на виявлення наявності симптомів посттравматичного стресового розладу (PCL-5). Опитувальник PCL-5 з критерієм A - це тест з 20 пунктів, розроблений для вимірювання симптомів ПТСР згідно з сучасним визначенням, зафіксованим в DSM-5 (Карачевський А.Б., 2016; Bovin M. J., 2015). Після ідентифікації найгіршої події за критерієм А, респонденти відповідають на запитання про різні симптоми і ступінь ï переживання впродовж останнього місяця. Відповіді оцінюються за шкалою Р. Лайкерта від 0 (зовсім ні) до 4 (дуже сильно). Максимальний загальний бал 80. Про значну вірогідність наявності ПТСР свідчать бали 45 і вище. Коефіцієнт альфа Кронбаха в загальній вибірці склав $\alpha=.94$.

\section{Етапи аналізу}

Спочатку був проведений порівняльний аналіз групи ветеранів з групою офіцерів за рівнем загального балу інтолерантності до 
different levels of IU. The analysis was performed using Student's t-test and Mann-Whitney U-test.

In the second stage, a correlation analysis of IU scores and PTSD symptoms was performed for the entire sample of veterans and for subgroups formed by the level of intolerance of uncertainty (the nonparametric Spearman's criterion $\rho$ was used). The calculations were performed using the program for statistical data processing SPSS 23.0.

\section{Results}

The servicemen groups total score and subcsales descriptive statistics of intolerance of uncertainty are presented in Table 1.

Comparison of the group of veterans with the group of officers on the general scale of the IUS-12 questionnaire did not show a significant difference in the level of intolerance of uncertainty. But a comparison of the mean values on the subscales (Student's t-test) made it possible to conclude that there was a significant difference between the groups on the "Inhibitory anxiety" subscale $(p<.05)$. The average values невизначеності та за субшкалами. Також дані двох груп були співставленні між собою для визначення різниці у рівні прояву ознак посттравматичного стресу у військовослужбовців з різним рівнем ITH. Аналіз проводився за допомогою t-критерія Стюдента та U-критерія Манна-Уітні.

На другому етапі був проведений кореляційний аналіз показників інтолерантності до невизначеності та симптомів ПТСР для всій вибірки ветеранів і для підгруп, сформованих за рівнем інтолерантності до невизначеності (використовувався непараметричний критерій $\rho$ Спірмена). Розрахунки проводились за допомогою програми для статистичної обробки даних SPSS 23.0.

\section{Результати}

Описові статистики відповідей двох груп військових за загальним балом інтолерантності до невизначеності та за субшкалами представлені у табл. 1.

Співставлення групи ветеранів 3 групою

Table 1. Descriptive statistics of intolerance of uncertainty in different groups

Таблиця 1. Описові статистики показників інтолерантності до невизначеності в різних групах

\begin{tabular}{|c|c|c|c|c|c|}
\hline $\begin{array}{l}\text { Scales } \\
\text { Шкали }\end{array}$ & $\alpha$ & $\mathbf{M}$ & SD & $\begin{array}{c}\text { Skew } \\
\text { Асиметрія }\end{array}$ & $\begin{array}{l}\text { Kurtosis } \\
\text { Ексцес }\end{array}$ \\
\hline \multicolumn{6}{|c|}{$\begin{array}{c}\text { Veterans, } n=32 \\
\text { Ветерани, } n=32\end{array}$} \\
\hline IUS-12 Total & .81 & 32.03 & 6.5 & -.27 & -.95 \\
\hline IUS-12 PA & .69 & 20.84 & 4.2 & -.19 & -.58 \\
\hline IUS-12 IA & .72 & 11.19 & 3.1 & -.28 & -.83 \\
\hline PCL-5 & .92 & 31.16 & 15 & -.21 & -.15 \\
\hline \multicolumn{6}{|c|}{$\begin{array}{c}\text { Officers, n=47 } \\
\text { Офіцери, n=47 }\end{array}$} \\
\hline IUS-12 Total & .81 & 29.96 & 5.6 & .6 & .97 \\
\hline IUS-12 PA & .72 & 20.17 & 4.3 & .75 & .75 \\
\hline IUS-12 IA & .71 & 9.78 & 3.0 & .61 & -.28 \\
\hline PCL-5 & .90 & 12.13 & 11.1 & 1.5 & 3.3 \\
\hline \multicolumn{6}{|c|}{$\begin{array}{c}\text { General group of servicemen }(n=79) \\
\text { Загальна група військовослужбовців }(n=79)\end{array}$} \\
\hline IUS-12 Total & .81 & 30.8 & 6.6 & .23 & -.32 \\
\hline IUS-12 PA & .71 & 20.4 & 4.2 & .29 & .04 \\
\hline IUS-12 IA & .72 & 10.4 & 3.1 & .05 & -.71 \\
\hline PCL-5 & .94 & 19.8 & 15.8 & .67 & -.34 \\
\hline
\end{tabular}

Note: IUS-12 Total - total score of the questionnaire "Intolerance of Uncertainty Scale"; IUS-12 PA - "Perspective anxiety" subscale; IUS-12 IA - "Inhibitory anxiety" subscale; PCL-5 - the total result of the PTSD symptoms questionnaire.

Примітка: IUS-12 Total - загальний бал опитувальника “Шкала інтолерантності до невизначеності”; IUS-12 PA - субшкала “тривога перед майбутнім"; IUS-12 IA - субшкала "гнітюча тривога"; PCL-5 - загальний результат по опитувальнику симптомів ПТСР. 
of Inhibitory anxiety were higher in groups of veterans with serious injuries.

Then the general group of servicemen $(n=79)$ was divided into two subgroups, formed by the level of intolerance of uncertainty (up to 29 points, and more than 31). Mann-Whitney $\mathrm{U}$ test revealed that there was a significant difference between two subgroups in the level of PTSD symptoms. That is, in the group with a higher level of intolerance of uncertainty, there were more of the post-traumatic stress signs, and this difference was significant for all clusters of symptoms.

According to the general level of PTSD signs, the group of veterans differs from the group of officers by higher scores. In the group of veterans, the number of people with a very high risk of developing PTSD (PCL-5 > 45) reached $19.0 \%$, and in the group of officers it was only $2.0 \%$.

As it can be seen from the Table 2, IU has a strong correlation with all clusters of PTSD symptoms. Weaker association is only with the group of symptoms related to changes in hyper arousal and reactivity, exaggerated startle response, excessive starting reaction, problems with concentration and sleep. Inhibitory anxiety has a stronger connection with all types of post-traumatic stress reactions than the scale of Perspective anxiety, except for the cluster E.

In the group of officers, no correlations were found between IU and signs of PTSD, because the vast majority of respondents had zero or close to zero values in the PCL-5 questionnaire.

Correlation analysis of IU with signs of PTSD in the group of veterans gave a completely different picture. The overall IU score correlated with all clusters of PTSD symptoms, only the subscales were not associated with marked alterations in arousal and reactivity. A thorough analysis of the correlations of IU with the items included in cluster $E$ showed that in the group of veterans the "Perspective anxiety" subscale significantly correlated with a sense of alertness and hypervigilance $(\rho=.41, p<.05)$. At the same time, "Inhibitory anxiety" had a positive correlation with complaints of problems with concentration $(\rho=.49, p<.01)$ and sleep $(\rho=.57$, $p<.01)$ at a statistically significant level. офіцерів за загальною шкалою опитувальника IUS-12 не показало значущої різниці в рівні інтолерантності до невизначеності. Але порівняння середніх значень за субшкалами (t-критерій Стюдента) дає можливість зробити висновок, що між групами $\epsilon$ значуща різниця за субшкалою “гнітюча тривога” (p <. 05). Середні значення гнітючої тривоги більш високі у групи ветеранів з важкими пораненнями.

Далі загальна група військових $(\mathrm{n}=79)$ була поділена на дві підгрупи, сформовані за рівнем інтолерантності до невизначеності (до 29 балів, та більш 31). В результаті аналізу за критерієм Манна-Уітні виявлено, що $є$ значуща різниця між двома підгрупами в рівні ознак ПТСР. Тобто у групи з більш високим рівнем інтолерантності до невизначеності прояви посттравматичного стресу вищі, і ця різниця значуща по всіх кластерах симптомів.

За загальним рівнем ознак ПТСР група ветеранів відрізняється від групи офіцерів більш високими балами. При цьому в групі ветеранів кількість осіб з дуже високим ризиком розвитку ПТCP (PCL-5 > 45) досягає 19.0\%, а в групі офіцерів тільки $2.0 \%$.

Як видно з таблиці 2, ITH має сильний зв'язок з усіма кластерами проявів посттравматичного стресового розладу. Слабкіший зв'язок тільки з групою симптомів, що стосуються змін у реакціях збудження і реактивності, перевищеної стартової реакції, проблемами 3 концентрацією та зі сном. Гнітюча тривога має більш сильний зв'язок з усіма типами реакцій посттравматичного стресу, ніж субшкала тривоги перед майбутнім, окрім кластеру “Е”.

У групі офіцерів не встановлено кореляцій між ITH та ознаками ПТСР, тому що переважна більшість респондентів має нульові або близькі до нуля значення за опитувальником PCL-5.

Кореляційний аналіз ITH з ознаками ПТСР у групі ветеранів дає зовсім іншу картину. Загальний бал ITH корелює з усіма кластерами ознак ПТСР, тільки за субшкалами не встановлено зв'язку з негативними змінами у процесах збудження і реактивності. Проведений грунтовний аналіз кореляцій ITH з питаннями, 
Table2. Correlations between clusters of PTSD symptoms and intolerance of uncertainty, Spearman's rank correlation $\rho$

Таблиця 2. Кореляційні зв'язки між кластерами симптомів ПТСР та інтолерантністю до невизначеності, $\rho$ Спірмена

\begin{tabular}{|c|c|c|c|c|c|c|c|c|}
\hline $\begin{array}{c}\text { Scale } \\
\text { Шкала }\end{array}$ & $\begin{array}{c}\text { IUS-12 } \\
\text { Total }\end{array}$ & PA & IA & PCL-5 & B & C & D & $\mathbf{E}$ \\
\hline \multicolumn{9}{|c|}{$\begin{array}{c}\text { Servicemen, } \mathrm{n}=79 \\
\text { Військовослужбовці, } \mathrm{n}=79\end{array}$} \\
\hline IUS-12 Total & 1 & $0.91^{* *}$ & $.87^{* *}$ & $.39 * *$ & $.38^{* *}$ & $.38^{* *}$ & $.34^{* *}$ & $.31^{* *}$ \\
\hline PA & & 1 & $.61^{* *}$ & $.31^{* *}$ & $.26^{* *}$ & $.29^{* *}$ & $.28^{* *}$ & $.22^{* *}$ \\
\hline IA & & & 1 & $.41^{* *}$ & $.45^{* *}$ & $.42^{* *}$ & $.34^{* *}$ & $.34^{* *}$ \\
\hline PCL-5 & & & & 1 & $.87^{* *}$ & $.79^{* *}$ & $.93^{* *}$ & $.86^{* *}$ \\
\hline \multicolumn{9}{|c|}{$\begin{array}{c}\text { Veterans, } n=32 \\
\text { Ветерани, } n=32\end{array}$} \\
\hline IUS-12 Total & 1 & $.94^{* *}$ & $.96^{* *}$ & $.64^{* *}$ & $.56^{* *}$ & $.64^{* *}$ & $.54^{* *}$ & $.37^{* *}$ \\
\hline PA & & 1 & $.64^{* *}$ & $.54^{* *}$ & $.43^{* *}$ & $.52^{* *}$ & $.48^{* *}$ & - \\
\hline IA & & & 1 & $.59^{* *}$ & $.55^{* *}$ & $.64^{* *}$ & $.51^{* *}$ & - \\
\hline PCL-5 & & & & 1 & $.79 * *$ & $.78^{* *}$ & $.86^{* *}$ & $.82^{* *}$ \\
\hline \multicolumn{9}{|c|}{$\begin{array}{c}\text { Officers, } n=47 \\
\text { Офіцери, n=47 }\end{array}$} \\
\hline IUS-12 Total & 1 & - & - & - & - & - & - & - \\
\hline PA & & 1 & $.55^{* *}$ & - & - & - & - & - \\
\hline IA & & & 1 & - & $.32^{*}$ & - & - & - \\
\hline PCL-5 & & & & 1 & $.77^{* *}$ & $.67^{* *}$ & $.86^{* *}$ & $.72^{* *}$ \\
\hline
\end{tabular}

Note: ${ }^{*}$ - the correlation is significant at the level of 0.05 ; ${ }^{* *}$ - correlation is significant at the level of 0.01 ; IUS-12 - N. Carleton's test of intolerance of uncertainty; PA - Perspective anxiety; IA - Inhibitory anxiety; clusters of PTSD symptoms: B - intrusions; C - avoidance behaviour; D - negative changes in thoughts and moods; E - marked alterations in arousal and reactivity; PCL-5 - the total score of the PTSD symptoms questionnaire.

Примітка: * - кореляція значуща на рівні 0,05 (двостороння); ** - кореляція значуща на рівні 0,01 (двостороння); IUS-12 - тест інтолерантності до невизначеності Н. Карлетона; PA - тривога перед майбутнім; IA - гнітюча тривога; кластери симптомів ПТСР: В - інтрузії; C - поведінка уникнення; D - негативні зміни в думках та настрої; Е - негативні зміни у процесах збудження і реактивності; PCL-5 - загальний результат по опитувальнику симптомів ПТСР.

\section{Discussion}

The comparison of two groups of servicemen in terms of the general level of intolerance of uncertainty did not show significant differences. At the same time, in absolute terms, the level of IU in the group of officers was slightly lower. The significant difference between groups of veterans and officers was on the "Inhibitory anxiety" subscale. This result may be due to the fact that officers have been taught and trained to act in conditions of uncertainty and therefore they respond to its presence more calmly. Another reason for the difference in the level of Inhibitory anxiety may be that in the group of veterans with serious injuries, the experience of encountering unforeseen events had catastrophic consequences for life and health, and test questions indirectly activated these memories, affected feelings and responses. які входять до кластеру Е, засвідчив, що в групі ветеранів субшкала “тривога перед майбутнім" значущо корелює з відчуттям настороженості та станом пильності $(\rho=.41, p<.05)$. Водночас, "гнітюча тривога" має додатну кореляцію із скаргами на проблеми 3 концентрацією $(\rho=.49, p<.01)$ та сном $(\rho=.57, p<.01)$ на статистично значущому рівні.

\section{Дискусія}

Співставлення двох груп військовослужбовців за загальним рівнем інтолерантності до невизначеності не показало значущих відмінностей. Водночас за абсолютними значеннями рівень ITH в групі офіцерів дещо нижчий. Значуща різниця між групами ветеранів і офіцерів $\epsilon$ за субшкалою “гнітюча тривога”. Такий результат може бути пов'язаний з тим, що офіцери 
In the group of veterans, the level of posttraumatic stress signs was much higher than in the group of officers. Primarily, this was due to the difference in the number and severity of combat experience and injuries. This connection was well studied and proven (Humeniuk, Fedchuk, 2016; Steele, 2017). A secondary factor might be the difference in the level of Inhibitory anxiety, which increased vulnerability to stress.

At the same time, the correlation analysis did not show an association of IU in Ukrainian veterans with symptoms of hyperarousal and reactivity, which differs from data, which had been obtained from samples of the US servicemen and students in previous studies (Fetzner et al., 2013; Oglesby et al., 2016; Oglesby, Gibby et al., 2017; Raines et al., 2019). This might be due to the specifics of the sample, as the group of veterans consisted mainly of motivated veterans who tamed their emotions. Correlation analysis of the answers to the questions of cluster E clarified the following: intolerance of uncertainty in veterans was associated with vigilance and problems with concentration and sleep. Examples of the IU correlation with sleep difficulties were studied previously and an indirect effect of IU on sleep quality due to anxiety and sensitivity to anxiety was found (Lauriola et al., 2019). Significantly fewer points were scored by the cluster's answers regarding outbursts of aggression towards others, selfdestructive behavior and exaggerated startle response. The reason for this difference might be precisely in the specifics of the aggression experience in athletes with disabilities, in particular their inherent "positive aggression" (Gluhova et al., 2017: 89). One of goals and value of participation in the "Invictus Games" is the opportunity to undergo rehabilitation, i.e. the achievement is the performance and participation in the competition, not victory, not the desire to get a result at any cost. This orientation shifts the expression of aggression from themselves or others to the process of preparation for competition. From a prognostic point of view, this distribution of responses in this cluster allows to make a positive assessment of the veterans' state, because previous studies have found a correlation between the level проходять навчання та тренуються діяти в умовах невизначеності і тому реагують на її наявність більш спокійно. Іншою причиною різниці в рівні гнітючої тривоги може бути те, що в групі ветеранів з важкими пораненнями набутий досвід зіткнення з несподіванками мав катастрофічні наслідки для життя і здоров'я, і питання тесту непрямим чином активували ці спогади, вплинули на переживання та відповіді.

В групі ветеранів рівень ознак посттравматичного стресу значно вищий, ніж в групі офіцерів. Це пов'язано, в першу чергу, з різницею в кількості бойового досвіду і отриманих пораненнях. Цей зв'язок $є$ добре вивченим й доведеним (Гуменюк, Федчук, 2016; Steele, 2017). Другорядним чинником може бути саме різниця у рівні гнітючої тривоги, яка збільшує вразливість до переживання стресу.

Одночасно кореляційний аналіз не показав зв'язку ITH у українських ветеранів з симптомами гіперзбудження та реактивності, що розходиться с деякими попередніми даними, отриманими на вибірках американських військових та студентах (Fetzner et al., 2013; Oglesby et al., 2016; Oglesby, Gibby et al., 2017; Raines et al., 2019). Це може бути пов'язано зі специфікою вибірки, адже група ветеранів складалась переважно з вмотивованих ветеранів, що приборкали свої емоції. Кореляційний аналіз відповідей на запитання кластеру Е прояснив це: інтолерантність до невизначеності у ветеранів пов'язана зі станом пильності та проблемами з концентрацією і сном. Приклади зв'язку ITH зі складнощами зі сном були досліджені раніш і виявили непрямий вплив ITH на якість сну через тривогу та сензитивність до тривожності (Lauriola et al., 2019). Значно менше балів набрали відповіді кластеру, що стосуються спалахів агресії у бік оточуючих, самопошкоджувальної поведінки та перевищеної стартової реакції. Причина цієї відмінності може полягати саме у специфіці прояву агресії у спортсменів з обмеженими можливостями, зокрема властивою їм “позитивною агресією” (Глухова та ін., 2017: 89). Однією з цілей і цінністю участі у "Іграх Нескорених" є можливість пройти реабілітацію, тобто досягненням $\epsilon$ сам виступ й участь у змаганнях, а не перемога, не бажання

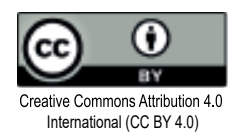


of hyper arousal symptoms with difficulty in recovery and chronic PTSD (Marshall, 2006).

In the group of veterans, the level of IU significantly correlated with all clusters of symptoms of post-traumatic stress. Similar results were also obtained from samples of civilians (Fetzner et al., 2013) and AfricanAmerican servicemen (Hollingsworth et al., 2018), although some researches did not confirm the contribution of IU to the development of negative changes in thoughts and moods (Raines et al., 2019) or re-experiencing a traumatic event-intrusions (Oglesby, Gibby et al., 2017). There is an assumption that the type of traumatic experience may affect the characteristics of uncertainty and the severity of certain signs of post-traumatic stress (Raines et al., 2019). For example, the presence of traumatic childhood experiences and the level of IU differently affect the choice of coping strategies and emotional reactions in overcoming stress (Hromova, 2020). But this connection needs further study.

\section{Conclusions}

Results of IU level comparing in two groups of servicemen showed that veterans differ from officers primarily in the "Inhibitory anxiety" subscale. According to the intolerance of uncertainty total score, no significant difference has been found.

A distinction of the correlation of intolerance of uncertainty level with signs of post-traumatic stress in the group of veterans with serious injuries is the lack of significant connection with the cluster E - hyper arousal and reactivity, in particular, outbursts of aggression and self-destructive behavior. This difference reflects the specifics of the experience and expression of aggression in athletes with disabilities.

Servicemen with a higher level of intolerance of uncertainty have more severe signs of post-traumatic stress, which was first studied in the Ukrainian sample and is in line with an array of data from foreign publications.

\section{Acknowledgements}

The author expresses gratitude to the public organization "Come Back Alive" for cooperation and support in collecting data for the study. отримати результат за будь-яку ціну. Ця спрямованість зміщує прояви агресії з себе або оточуючих на процес підготовки до змагань. 3 прогностичного погляду, такий розподіл відповідей в цьому кластері дає можливість позитивної оцінки стану ветеранів, бо попередні дослідження виявили зв'язок між рівнем симптомів гіперзбудження зі складністю у відновленні та хронічним перебігом ПТСР (Marshall, 2006).

У групі ветеранів рівень ITH значущо корелює з усіма кластерами симптомів посттравматичного стресу. Подібні результати були також отримані на вибірках цивільних (Fetzner et al., 2013) та військових-афроамериканців (Hollingsworth et al., 2018), хоч деякі дослідження не підтверджують внесок ITH у розвиток негативних змін думок і настрою (Raines et al., 2019) або повторне переживання травматичної події - інтрузій (Oglesby, Gibby et al., 2017). Висловлюється припущення, що тип отриманого травматичного досвіду може впливати на особливості переживання невизначеності та прояв тих чи інших ознак посттравматичного стресу (Raines et al., 2019). Наявність, наприклад, травматичного дитячого досвіду та рівень ITH по-різному впливають на вибір копінг-стратегій та емоційні реакції при подоланні стресу (Громова, 2020). Але цей зв'язок потребує подальшого вивчення.

\section{Висновки}

В результаті порівняння двох груп військовослужбовців за рівнем інтолерантності до невизначеності можна стверджувати, що ветерани відрізняються від офіцерів насамперед за субшкалою “гнітюча тривога”. За загальним балом інтолерантності до невизначеності значущої різниці не встановлено.

Особливістю кореляції інтолерантності до невизначеності з ознаками посттравматичного стресу в групі ветеранів, що мають важкі поранення, $\epsilon$ відсутність значущого зв'язку з кластером "E" - гіперзбудження та реактивність, зокрема, спалахів агресії та самопошкоджувальної поведінки. Ця відмінність відображає специфіку переживання та прояву агресії у спортсменів з обмеженими можливостями. 


\section{References}

Banducci, A. N., Bujarski, S. J., Bonn-Miller, M. O., Patel, A. \& Connolly, K. M. (2016). The impact of intolerance of emotional distress and uncertainty on veterans with co-occurring PTSD and substance use disorders. Journal of Anxiety Disorders, 41, 73-81. DOI: 10.1016/j.janxdis.2016.03.003

Boelen, P. A. (2019). Intolerance of uncertainty predicts analogue posttraumatic stress following adverse life events. Anxiety, Stress, \& Coping, 32(5), 498504. DOI: $10.1080 / 10615806.2019 .1623881$

Bovin, M. J., Marx, B. P., Weathers, F. W., Gallagher, M. W., Rodriguez, P., Schnurr, P. P., Keane, T. M. (2015). Psychometric Properties of the PTSD Checklist for Diagnostic and Statistical Manual of Mental Disorders-Fifth Edition (PCL-5) in Veterans. Psychological Assessment, 2015. Advance online publication. http://dx.doi.org/10.1037/pas0000254

Carleton, R. N., Norton, M. A. P. J. \& Asmundson, G. J. G. (2007). Fearing the unknown: A short version of the Intolerance of Uncertainty Scale. Journal of Anxiety Disorders, 21(1), 105-117. DOI: 10.1016/j.janxdis.2006.03.014

Fetzner, M. G., Horswill, S. C., Boelen, P. A., \& Carleton, R. N. (2013). Intolerance of Uncertainty and PTSD Symptoms: Exploring the Construct Relationship in a Community Sample with a Heterogeneous Trauma History. Cognitive Therapy and Research, 37(4), 725-734. DOI: 10.1007/ s10608-013-9531-6

Freeston, M. H., Rhéaume, J., Letarte, H., Dugas, M. J. \& Ladouceur, R. (1994). Why do people worry? Personality and Individual Differences, 17(6), 791802. DOI: 10.1016/0191-8869(94)90048-5

Gluhova, V., Maltseva, A., Koltynov, E., \& Halabov, A. (2017). Peculiarities of Aggressiveness and its Correlation with Decision-Making Parameters in Disabled and Able-Bodied Athletes. Human. Sport. Medicine, 17(5), 85-94. DOI: 10.14529/hsm17s09

Humeniuk, L. Y., Fedchuk, O. V. (2016). Research of post-traumatic stress disorder and directions of psychorehabilitation of victims of military psychotraumas. Scientific Bulletin of Lviv State University of Internal Affairs. 1, 228-240. Retrieved from:http://www.lvduvs.edu.ua/documents_pdf/ visnyky/nvsp/01_2016/16glivvp.pdf

Hollingsworth, D. W., Gauthier, J. M., McGuire, A. P., Peck, K. R., Hahn, K. S., \& Connolly, K. M. (2018). Intolerance of Uncertainty Mediates Symptoms of PTSD and Depression in African American Veterans With Comorbid PTSD and Substance Use Disorders. Journal of Black Psychology, 44(7), $667-$ 688. DOI: $10.1177 / 0095798418809201$

Hromova, H. (2020). Research measures of correlation between uncertainty intolerance and adverse life experience outcomes. Scientific Studios on
Військовослужбовці з більш високим рівнем інтолерантності до невизначеності мають більш важки прояви посттравматичного стресу, що вперше було досліджено на українській вибірці і узгоджується з масивом даних зарубіжних публікацій.

\section{Подяка}

Авторка висловлює подяку громадській організації “Повернись живим" ("Come back Alive”) за співробітництво і допомогу в зборі даних для дослідження.

\section{Список використаних джерел}

Banducci, A. N., Bujarski, S. J., Bonn-Miller, M. O., Patel, A. \& Connolly, K. M. (2016). The impact of intolerance of emotional distress and uncertainty on veterans with co-occurring PTSD and substance use disorders. Journal of Anxiety Disorders, 41, 73-81. DOI: $10.1016 /$ j.janxdis.2016.03.003

Boelen, P. A. (2019). Intolerance of uncertainty predicts analogue posttraumatic stress following adverse life events. Anxiety, Stress, \& Coping, 32(5), 498-504. DOI: $10.1080 / 10615806.2019 .1623881$

Bovin, M. J., Marx, B. P., Weathers, F. W., Gallagher, M. W., Rodriguez, P., Schnurr, P. P., Keane, T. M. (2015). Psychometric Properties of the PTSD Checklist for Diagnostic and Statistical Manual of Mental Disorders-Fifth Edition (PCL-5) in Veterans. Psychological Assessment, 2015. Advance online publication. http://dx.doi.org/10.1037/pas0000254

Carleton, R. N., Norton, M. A. P. J. \& Asmundson, G. J. G. (2007). Fearing the unknown: A short version of the Intolerance of Uncertainty Scale. Journal of Anxiety Disorders, 21(1), 105-117. DOI: 10.1016/j.janxdis.2006.03.014

Fetzner, M. G., Horswill, S. C., Boelen, P. A., \& Carleton, R. N. (2013). Intolerance of Uncertainty and PTSD Symptoms: Exploring the Construct Relationship in a Community Sample with a Heterogeneous Trauma History. Cognitive Therapy and Research, 37(4), 725-734. DOI: 10.1007/s10608-0139531-6

Freeston, M. H., Rhéaume, J., Letarte, H., Dugas, M. J. \& Ladouceur, R. (1994). Why do people worry? Personality and Individual Differences, 17(6), 791-802. DOI: 10.1016/0191-8869(94)90048-5

Gluhova, V., Maltseva, A., Koltynov, E., \& Halabov, A. (2017). Peculiarities of Aggressiveness and its Correlation with Decision-Making Parameters in Disabled and Able-Bodied Athletes. Human. Sport. Medicine, 17(5), 85-94. DOI: 10.14529/hsm17s09

Гуменюк Л. Й., Федчук О. В. (2016). Дослідження посттравматичного стресового розладу 
Social and Political Psychology, 45(48), 88-99. DOI: $10.33120 /$ ssj.vi45(48).145

Lauriola, M., Carleton, R. N., Tempesta, D., Calanna, P., Socci, V., Mosca, O. et al. (2019). A Correlational Analysis of the Relationships among Intolerance of Uncertainty, Anxiety Sensitivity, Subjective Sleep Quality, and Insomnia Symptoms. International Journal of Environmental Research and Public Health, 16(18), 3253. DOI: 10.3390/ ijerph 16183253

Marshall, G. N., Schell, T. L., Glynn, S. M., \& Shetty, V. (2006).The role of hyperarousal in the manifestation of posttraumatic psychological distress following injury. Journal of Abnormal Psychology, 115(3), 624-628. DOI: 10.1037/0021-843x.115.3.624

Oglesby, M. E., Boffa, J. W., Short, N. A., Raines, A. M., \& Schmidt, N. B. (2016). Intolerance of uncertainty as a predictor of post-traumatic stress symptoms following a traumatic event. Journal of Anxiety Disorders, 41, 82-87. DOI: 10.1016/j. janxdis.2016.01.005

Oglesby, M. E., Gibby, B. A., Mathes, B. M., Short, N. A. \& Schmidt, N. B. (2017). Intolerance of uncertainty and post-traumatic stress symptoms: An investigation within a treatment seeking trauma-exposed sample. Comprehensive Psychiatry, 72, 34-40. DOI: 10.1016/j.comppsych.2016.08.011

Pidchasov, E. V., Lomakin, H. I. (2011). PTSD symptoms social and psychological analysis in combatants. Problems of extreme and crisis psychology. 10, 86-98. Retrieved from:https://nuczu.edu.ua/ sciencearchive/ProblemsOfExtremeAndCrisisPsychology/vol10/013.pdf

Karachevskyi, A. B. (2016). Adaptation of PTSD scales and questionnaires for Ukrainian and Russian languages. Collection of scientific works of the P.L.Shupyka NMAPO, 25, 607-622.

Raines, A. M., Oglesby, M. E., Walton, J. L., True, G. \& Franklin, C. L. (2019). Intolerance of uncertainty and DSM-5 PTSD symptoms: Associations among a treatment seeking veteran sample. Journal of Anxiety Disorders, 62, 61-67. DOI: 10.1016/j. janxdis.2018.12.002

Saulnier, K. G., Allan, N. P., Raines, A. M. \& Schmidt, N. B. (2019). Depression and Intolerance of Uncertainty: Relations between Uncertainty Subfactors and Depression Dimensions. Psychiatry, 1-8. DOI:1 $0.1080 / 00332747.2018 .1560583$

Steele, M., Germain, A. \& Campbell, J. S. (2017). Mediation and Moderation of the Relationship Between Combat Experiences and Post-Traumatic Stress Symptoms in Active Duty Military Personnel. Military Medicine, 182(5), e1632-e1639.DOI: 10.7205/ milmed-d-16-00169

Trivedi, R. B., Post, E. P., Sun, H., Pomerantz, A., Saxon, A. J., Piette, J. D. et al. (2015). Prevalence, і напрямків психореабілітації постраждалих від воєнних психотравм. Науковий вісник Львівського державного університету внутрішніх справ. 1, 228-240. Retrieved from: http://www.lvduvs.edu.ua/documents_pdf/ visnyky/nvsp/01_2016/16glivvp.pdf

Hollingsworth, D. W., Gauthier, J. M., McGuire, A. P., Peck, K. R., Hahn, K. S., \& Connolly, K. M. (2018). Intolerance of Uncertainty Mediates Symptoms of PTSD and Depression in African American Veterans With Comorbid PTSD and Substance Use Disorders. Journal of Black Psychology, 44(7), 667-688. DOI: $10.1177 / 0095798418809201$

Hromova, H. (2020). Research measures of correlation between uncertainty intolerance and adverse life experience outcomes. Scientific Studios on Social and Political Psychology, 45(48), 88-99. DOI: $10.33120 /$ ssj.vi45(48).145

Lauriola, M., Carleton, R. N., Tempesta, D., Calanna, P., Socci, V., Mosca, O., ... Ferrara, M. (2019). A Correlational Analysis of the Relationships among Intolerance of Uncertainty, Anxiety Sensitivity, Subjective Sleep Quality, and Insomnia Symptoms. International Journal of Environmental Research and Public Health, 16(18), 32-53. DOI: 10.3390/ ijerph16183253

Marshall, G. N., Schell, T. L., Glynn, S. M., \& Shetty, V. (2006). The role of hyperarousal in the manifestation of posttraumatic psychological distress following injury. Journal of Abnormal Psychology, 115(3), 624-628. DOI: 10.1037/0021-843x.115.3.624

Oglesby, M. E., Boffa, J. W., Short, N. A., Raines, A. M., \& Schmidt, N. B. (2016). Intolerance of uncertainty as a predictor of post-traumatic stress symptoms following a traumatic event. Journal of Anxiety Disorders, 41, 82-87. DOI: 10.1016/j. janxdis.2016.01.005

Oglesby, M. E., Gibby, B. A., Mathes, B. M., Short, N. A. \& Schmidt, N. B. (2017). Intolerance of uncertainty and post-traumatic stress symptoms: An investigation within a treatment seeking trauma-exposed sample. Comprehensive Psychiatry, 72, 34-40. DOI: 10.1016/j.comppsych.2016.08.011

Pidchasov E.V., Lomakin H.I. (2011) PTSD symptoms social and psychological analysis in combatants. Problems of extreme and crisis psychology. 10, 86-98. Retrieved from: https://nuczu.edu.ua/sciencearchive/ProblemsOfExtremeAndCrisisPsychology/vol10/013.pdf

Karachevskyi A. B. (2016). Adaptation of PTSD scales and questionnaires for Ukrainian and Russian languages/ Collection of scientific works of the P.L.Shupyka NMAPO, 25/2016, 607622.

Raines, A. M., Oglesby, M. E., Walton, J. L., True, G. \& Franklin, C. L. (2019). Intolerance of uncertainty

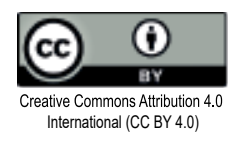


Comorbidity, and Prognosis of Mental Health Among US Veterans. American Journal of Public Health, 105(12), 2564-2569. DOI: 10.2105/ ajph.2015.302836

Tytarenko, T. (2020). Socio-psychological support of post-traumatic personal transformations. Scientific Studios on Social and Political Psychology, (45(48), 59-68. DOI: 10.33120/ssj.vi45(48).142

Tytarenko, T. M. (2019). Socio-psychological technologies of personality recovery after traumatic events - Practical guide / Ed. Tytarenko T.M. / NAES of Ukraine, Institute of Social and Political Psychology. Kropyvnytskyi: Imex-LTD, Retrieved from: https://www.academia.edu/40028931/

Weathers, F. W., Litz, B., Keane, T., Palmieri, P., Marx, B., \& Schnurr, P. (2013). The PTSD

checklist for DSM-5 (PCL-5). Scale available from the National Center for PTSD at www. ptsd. va. gov.

Zerach, G. \& Levi-Belz, Y. (2019). Intolerance of Uncertainty Moderates the Association Between Potentially Morally Injurious Events and Suicide Ideation and Behavior Among Combat Veterans. Journal of Traumatic Stress, 32(3), 424-436. DOI: 10.1002/ jts. 22366 and DSM-5 PTSD symptoms: Associations among a treatment seeking veteran sample. Journal of Anxiety Disorders, 62, 61-67. DOI: 10.1016/j. janxdis.2018.12.002

Saulnier, K. G., Allan, N. P., Raines, A. M., Schmidt, N. B. (2019). Depression and Intolerance of Uncertainty: Relations between Uncertainty Subfactors and Depression Dimensions. Psychiatry, 1-8. DOI:1 0.1080/00332747.2018.1560583

Steele, M., Germain, A. \& Campbell, J. S. (2017). Mediation and Moderation of the Relationship Between Combat Experiences and Post-Traumatic Stress Symptoms in Active Duty Military Personnel. Military Medicine, 182(5), e1632-e1639. DOI: 10.7205/ milmed-d-16-00169

Trivedi, R. B., Post, E. P., Sun, H., Pomerantz, A., Saxon, A. J., Piette, J. D., ... Nelson, K. (2015). Prevalence, Comorbidity, and Prognosis of Mental Health Among US Veterans. American Journal of Public Health, 105(12), 2564-2569. DOI: 10.2105/ ajph.2015.302836

Tytarenko, T. (2020). Socio-psychological support of post-traumatic personal transformations. Scientific Studios on Social and Political Psychology, (45(48), 59-68. DOI: 10.33120/ssj.vi45(48).142

Tytarenko T. M. (2019) Socio-psychological technologies of personality recovery after traumatic events - Practical guide/Ed. Tytarenko T.M./ NAPS of Ukraine, Institute of Social and Political Psychology. - Kropyvnytskyi: Imex-LTD, 2019. P. 220.

Zerach, G. \& Levi-Belz, Y. (2019). Intolerance of Uncertainty Moderates the Association Between Potentially Morally Injurious Events and Suicide Ideation and Behavior Among Combat Veterans. Journal of Traumatic Stress, 32(3), 424-436. DOI: 10.1002/ jts.22366 